\title{
Journal of \\ Gastroenterology and Hepatology Research
}

\section{Pulmonary Resection For Solitary Metastasis From Pancreatic Cancer}

\author{
Takahisa Fujikawa, Kenji Ono
}

Takahisa Fujikawa, Department of Surgery, Kokura Memorial Hospital, Kitakyushu, Fukuoka, Japan

Kenji Ono, Department of Respiratory Surgery, Kokura Memorial Hospital, Kitakyushu, Fukuoka, Japan

Conflict-of-interest statement: The authors declare that there is no conflict of interest regarding the publication of this paper.

Open-Access: This article is an open-access article which was selected by an in-house editor and fully peer-reviewed by external reviewers. It is distributed in accordance with the Creative Commons Attribution Non Commercial (CC BY-NC 4.0) license, which permits others to distribute, remix, adapt, build upon this work noncommercially, and license their derivative works on different terms, provided the original work is properly cited and the use is noncommercial. See: http://creativecommons.org/licenses/by-nc/4.0/

Correspondence to: Takahisa Fujikawa, MD, PhD, FACS, Department of Surgery, 3-2-1 Asano, Kokurakita-ku, Kitakyushu, Fukuoka 802-8555, Japan.

Email: fujikawa-t@kokurakinen.or.jp

Telephone: +81-93-511-2000

Fax: $+81-93-511-3240$

Received: July 10, 2018

Revised: September 9, 2018

Accepted: September 10, 2018

Published online: October 21, 2018

\footnotetext{
ABSTRACT

Pancreatic cancer is still one of the most lethal cancer diseases, and recurrence occurs in more than $80 \%$ of the patients even though curative resection was achieved. We experienced a case of pulmonary resection for solitary lung metastasis of the pancreatic cancer that developed after pancreaticoduodenectomy and following adjuvant chemotherapy. The postoperative course was uneventful and longterm survival was achieved. Pulmonary resection could improve the prognosis of selected patients who are suffering from lung metastasis of pancreatic cancer, and can be considered as a treatment option.
}

Key words: Pulmonary resection; Solitary metastasis; Pancreatic cancer

(C) 2018 The Author(s). Published by ACT Publishing Group Ltd. All rights reserved.

Fujikawa T, Ono K. Pulmonary Resection For Solitary Metastasis From Pancreatic Cancer. Journal of Gastroenterology and Hepatology Research 2018; 7(5): 2717-2719 Available from: URL: http:// www.ghrnet.org/index.php/joghr/article/view/2379

\section{LETTER TO THE EDITOR}

An 80-year-old man showed elevated serum amylase and CA19-9 levels during his medical check-up. Further examination including CT scan, MRCP and ERCP/EUS revealed the pancreatic head tumor, $1.5 \times 1.2 \mathrm{~cm}$ in size, with slightly dilated main paincreatic duct and bile duct (Figure 1A-1C), which suggested highly suspected pancreatic cancer. He underwent subtotal stomach-preserving pancreaticoduodenectomy and the tumor was histologically diagnosed as moderately differentiated adenocarcinoma (Figure 1D). Subsequently, he received six cycles of gemcitabine-based adjuvant chemotherapy. He had no evidence of disease for 24 months after surgery, but his following work up including enhanced CT scan revealed new solitary lesion in his left upper lung, $0.5 \times 0.5 \mathrm{~cm}$ in size, which was suspected for recurrence of pancreatic cancer (Figure 2A). Because the size of the nodule gradually increased (Figure 2B) but no other lesions detected at any organs, he underwent thoracoscopic wedge resection of the left upper lung. The nodule was histologically diagnosed as a metastasis from pancreatic cancer (Figure 2C, 2D). The patient received additional gemcitabine-based chemotherapy after the second operation without any significant adverse drug events, and he is still doing well without any recurrence 10 months after the second operation (36 months after the first operation).

Pancreatic cancer is still one of the most deadly cancers, with the 5 -year survival rate of less than $20 \%$ even after curative resection ${ }^{[1,2]}$. Median survival for patients receiving surgical resection is only 12.6 months, and the high recurrence rate is the main reason of the very poor prognosis ${ }^{[3]}$. Lung metastasis from pancreatic cancer is often multiple and is accompanied by metastatic lesions of other organs; resection of pulmonary metastasis from pancreatic cancer 

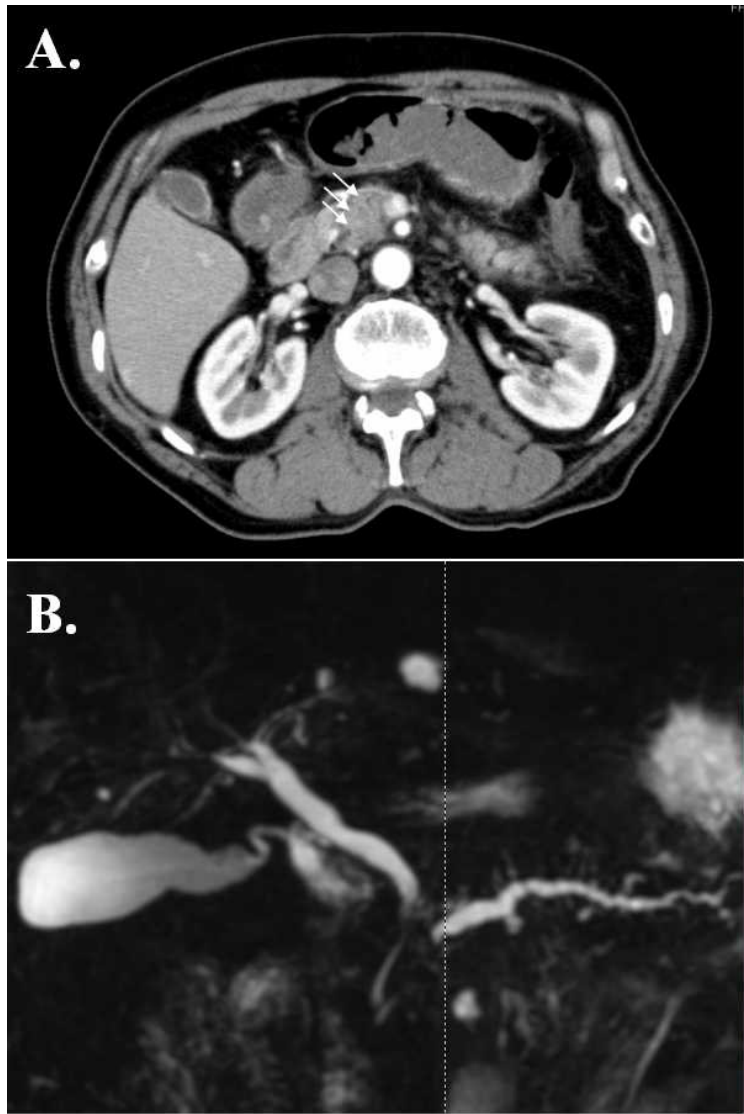

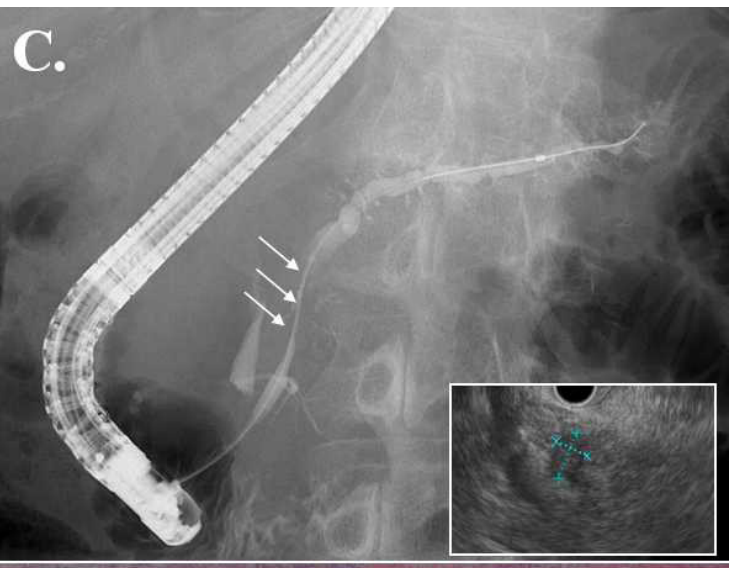

D.

Fure 1 (A) Enhanced CT scan of the abdomen demonstrated undemarcated low-density mass in the pancreatic head (white arrows). (B) MRCP showed slightly dilated extrahepatic bile duct and main pancreatic duct. (C) ERCP showed irregular narrowing of the main pancreatic duct (white arrows), and EUS (small image shown lower right) detected small mass lesion, $1.5 \times 1.2 \mathrm{~cm}$ in size in the head of the pancreas. (D) The resected tumor was histologically diagnosed as moderately differentiated adenocarcinoma.
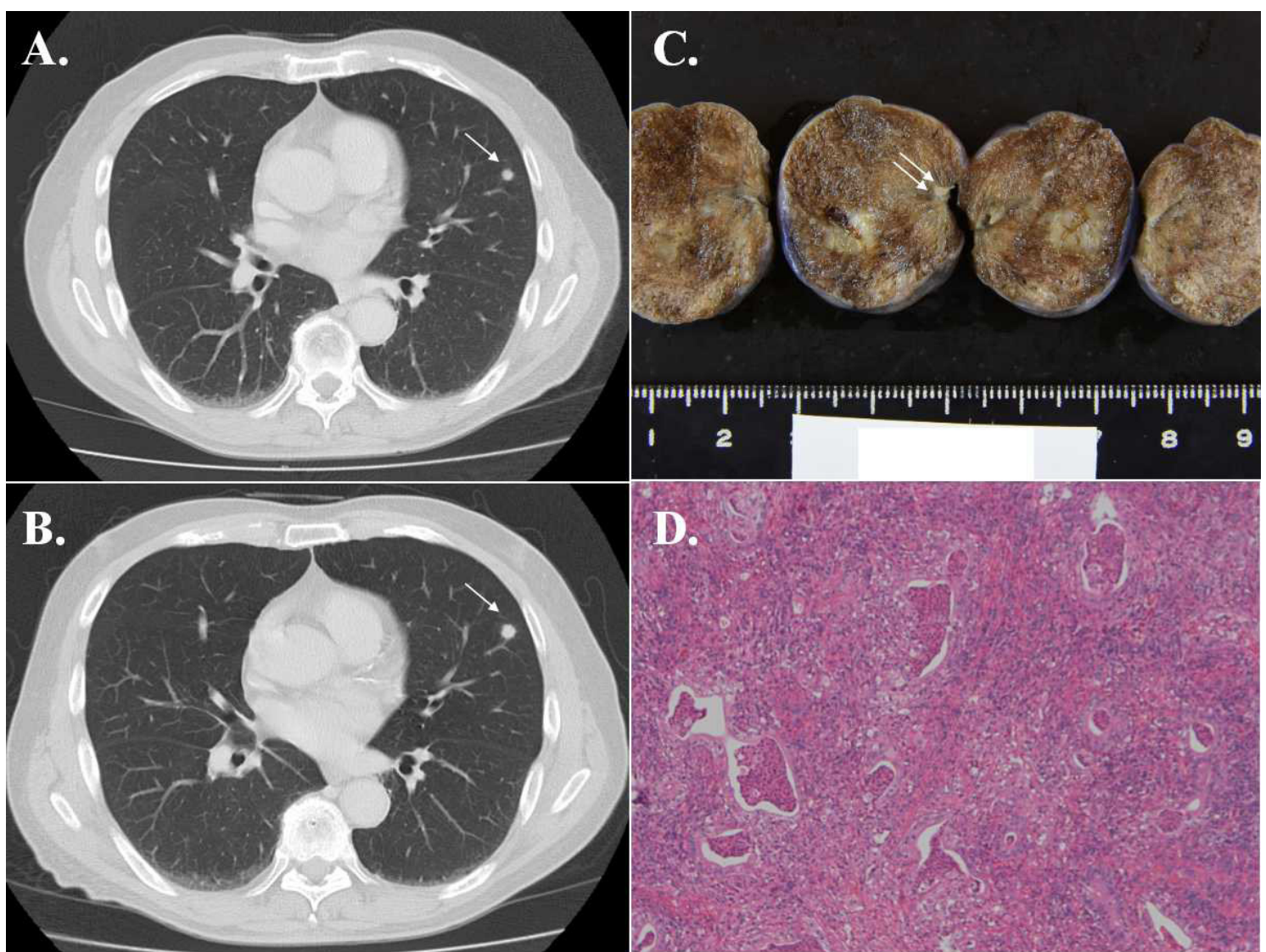

Figure 2 (A, B) Follow-up CT scan 24 months after surgery revealed new solitary lesion in his left upper lung (a white arrow), $0.5 \times 0.5$ $\mathrm{cm}$ in size, which was gradually enlarged during 3-month interval. (C, D) He underwent thoracoscopic wedge resection of the left upper lung, and the nodule (white arrows in Figure 2C) was histologically diagnosed as a metastasis from pancreatic cancer. 
is rare and the majority of these patients are treated with palliative chemotherapy. However, lung resection should be considered if the patient met the following criteria; (1) surgical intervention can be tolerated, (2) the primary lesion can be controlled, and (3) extrapulmonary metastases are not present or can be controlled $d^{[4,5]}$. When the lesions are multiple, surgical resection might be considered if all the lesions are stable over time and are estimated to be resectable. If the lung lesion is detected after pancreatic cancer resection and it is difficult to differentiate primary lung cancer from lung metastasis, lung resection should also be considered if the patient can tolerate surgery ${ }^{[6]}$. Additionally, some reports suggested that a long interval (e.g. 2 years or more) between the initial pancreatic resection and lung resection is related to long-term survival, like the current case ${ }^{[6,7]}$. Thus, if patients meet these conditions, lung resection might be considered.

\section{REFERENCES}

1. Schnelldorfer T, Ware AL, Sarr MG, Smyrk TC, Zhang L, Qin R, Gullerud RE, Donohue JH, Nagorney DM, Farnell MB. LongTerm Survival After Pancreatoduodenectomy for Pancreatic Adenocarcinoma. Ann Surg. 2008; 247(3): 456-462. [PMID: 18376190]; [DOI: 10.1097/SLA.0b013e3181613142]

2. Hsu CC, Herman JM, Corsini MM, Winter JM, Callister MD, Haddock MG, Cameron JL, Pawlik TM, Schulick RD, Wolfgang CL, Laheru DA, Farnell MB, Swartz MJ, Gunderson LL, Miller RC. Adjuvant chemoradiation for pancreatic adenocarcinoma: the Johns Hopkins Hospital-Mayo Clinic collaborative study. Ann Surg Oncol. 2010; 17(4): 981-990. [PMID: 20087786]; [PMCID:
PMC2840672]; [DOI: 10.1245/s10434-009-0743-7]

3. Bilimoria KY, Bentrem DJ, Ko CY, Ritchey J, Stewart AK, Winchester DP, Talamonti MS. Validation of the 6th edition AJCC pancreatic cancer staging system. Cancer. 2007; 110(4): 738-744. [PMID: 17580363]; [DOI: 10.1002/cncr.22852]

4. Arnaoutakis GJ, Rangachari D, Laheru DA, Iacobuzio-Donahue CA, Hruban RH, Herman JM, Edil BH, Pawlik TM, Schulick RD, Cameron JL, Meneshian A, Yang SC, Wolfgang CL. Pulmonary resection for isolated pancreatic adenocarcinoma metastasis: an analysis of outcomes and survival. J Gastrointest Surg. 2011; 15(9): 1611-1617. [PMID: 21725701]; [PMCID: PMC3160502]; [DOI: 10.1007/s11605-011-1605-8]

5. Okui M, Yamamichi T, Asakawa A, Harada M, Horio H. Resection for Pancreatic Cancer Lung Metastases. Korean $J$ Thorac Cardiovasc Surg. 2017; 50: 326-328. [PMID: 29124023]; [PMCID: PMC5628959]; [DOI: 10.5090/kjtcs.2017.50.5.326]

6. Katz MH, Wang H, Fleming JB, Sun CC, Hwang RF, Wolff RA, Varadhachary G, Abbruzzese JL, Crane CH, Krishnan S, Vauthey JN, Abdalla EK, Lee JE, Pisters PW, Evans DB. Long-term survival after multidisciplinary management of resected pancreatic adenocarcinoma. Ann Surg Oncol. 2009; 16(4): 836-847. [PMID: 19194760]; [PMCID: PMC3066077]; [DOI: 10.1245/s10434-0080295-2]

7. Brieau B, Barret M, Rouquette A, Dréanic J, Brezault C, Regnard $\mathrm{JF}$, Coriat R. Resection of Late Pulmonary Metastases from Pancreatic Adenocarcinoma: Is Surgery an Option? Cancer Invest. 2015; 33(10): 522-525. [PMID: 26461032]; [DOI: 10.3109/07357907.2015.1080831]

Peer Reviewer: Premashish Halder 